\title{
Beyond psychology: Spirituality in Henri Nouwen's pastoral care
}

\author{
Yolanda Dreyer \\ Department of Practical Theology \\ University of Pretoria
}

\begin{abstract}
This article aims to explain Henri Nouwen's reflection on the relationship between psychology and practical theology and especially on the commensurability/incommensurability of psychological techniques and spirituality, both of which are relevant to pastoral care. It demonstrates Nouwen's understanding of pastoral care, what the underlying epistemology is and how spirituality is the focal point of his model. In this context he discusses aspects such as pain, anger, greed, grief and solitude. In the discussion his knowledge and use of psychological perspectives become apparent. He sees the suffering person as a spiritual being, someone who lives in the presence of God. Therefore he finds it imperative to move beyond psychology. Spirituality is about the way in which someone experiences God's presence. To explain and enhance spirituality, Nouwen proposes a theory for pastoral care which aims at healing, sustaining and guiding the suffering person. To elucidate the underlying epistemology of Nouwen's model and to understand his critical stance with regard to psychology, the article follows the pattern of the focal points "healing", "sustaining" and "guiding".
\end{abstract}

\section{INTRODUCTION}

In his diary, published as The road to daybreak: A spiritual journey (1988), Henri Nouwen (1932-1996) mentions the existential phenomenologist Martin Heidegger as having had a great influence on his life (see Nouwen 1988:133). (For a biography of the life of Nouwen, see Beumer [1996] 1997.) Heidegger advocated a "hermeneutic of facticity" to address someone's "being in the world" (Dasein), his or her "authentic identity" (what ought to be). According to Heidegger (in 


\section{Beyond psychology: Spirituality in Henri Nouwen's pastoral care}

Collins \& Selina [1999] 2001:63), authenticity does not actualise on account of what I am (Sein), but because of my existence (Dasein): "It is not I myself who for the most part and on average am my Dasein, but the Others ... Dasein is subject to take-over bids by the Others. It exists as an 'I am' but also as an 'I-am-withthe-Others." Beryl Curt (1994:34) explains this "facticity" as follows: "By facticity Heidegger meant the contingency of our being onto and into a world always, already there. Meaning comes from our temporality and contingency." With regard to spirituality, "the Other" is God. "I-am-with-the-Others" is "Dasein", existence in relationship with God, myself and fellow human beings.

From this perspective, Nouwen questioned the use of psychological techniques for pastoral care. According to Nouwen (1988:133), Heidegger "calls for an attitude in which we say 'yes' to the new techniques, insofar as they serve our daily lives, and 'no' when they claim our whole being .... It is clear how important Heidegger's thoughts remain today. We need to safeguard our reflective minds more than ever. Indirectly, Heidegger also touches on the need for a new spirituality, a new way of being in the world without being of it." In his approach to spirituality Nouwen accepted some of the new techniques of psychology as useful while others were discarded (see Gillespie 2002:113). In Nouwen's frame of reference the concepts "pastoral care" and "spirituality" are linked. Spirituality can be explained as an individual's religious experience and, according to Gerben Heitink (1993:35), pastoral care is "searching with people for a way in which to experience their situation in the presence of God."

Heitink (1997:574) expresses an appreciation for the person and work of Henri Nouwen. He is especially appreciative of Nouwen's emphasis on the relationship between pastoral care and spirituality (Heitink [1998] 2000:85). In an article on Nouwen's spirituality, Kevin Gillespie (2002:116) observes that Nouwen's spirituality incorporates, but also goes beyond the epistemology of psychology. In an interview with Todd Brennan (1982:182) Nouwen emphasised that it was important not "to deny the validity of the question that is shaped by the psychological perspective, but to say that there is a new level of questioning 
which opens new perspectives and basically puts the question in a wholly different context, the context of God's reconciliation of the world in Jesus Christ."

Throughout his work Nouwen points out the limits of psychology for spirituality (Gillespie 2002:118; cf Ruffing 1990:47-59). In this critique Nouwen makes a valuable contribution to the theological discourse. Epistemological reflection with regard to the use of the social sciences, such as psychology, sociology and anthropology, has often been avoided by theologians. Theology seldom considers the philosophical theories behind scientific methods and the potential value of the humanities and social sciences for the theological discourse (see Browning 1996:81). Another issue which is often not considered, is whether the inherent values of the social sciences are commensurable with the core value of theology, namely spirituality.

This article builds on Gillespie's observation that Henri Nouwen reflected on the relationship between psychology and practical theology and especially on the commensurability/incommensurability of psychological techniques and spirituality, both of which are relevant to pastoral care. The article explains Nouwen's critique by elucidating the significance of spirituality in his reflection on pastoral care. The article moves towards an epistemological inconclusion (i e, a "way of knowing" which is unheimlich) about the role of psychology in pastoral care in a postmodern context. An epistemology is a theory concerned with questions such as: "how can we know" and "how can we know that we know" (Curt 1994:236)? Theories, models and methods of understanding are needed in order to validate/falsify a specific way of knowing. Unheimlichkeit is a term used by Heidegger to explain the concept "uncertainty" in a positive way. To be conscious of not-knowing helps to avoid "methodolotary" (Curt 1994:106) - the fallacy "that if you learn how to follow the map from a 'research question' by means of a test of choice-competency" with regard to qualitative or quantitative research, deductive or inductive methods, one will reach a compelling "conclusion".

The application of psychological techniques to "measure" spirituality or to enhance pastoral care is limited by the essentialistic positivistic nature of 


\section{Beyond psychology: Spirituality in Henri Nouwen's pastoral care}

psychology as such. Nouwen's model of pastoral care which aims at healing, sustaining and guiding confirms such limitation. One can say that psychology is the "science of measuring (mental) things that do not exist" (Curt 1994:241). According to Curt (1994:235) most of psychology today is still essentialist, empiricist and positivistic. For example, the assumption behind intelligence testing in psychology is that actions or responses to questions manifest some underlying essence of intelligence which, therefore, can be measured (Curt 1994:236). An empiricist epistemology assumes that we accumulate knowledge of reality "only through the exercises of our senses (albeit aided by various methods and techniques)" (Curt 1994:235). Thus empiricists tend to adhere to a realist ontology, in Heidegger's terms Sein, and in Nouwen's language "being in the world". Yet, empiricists incline to dismiss so-called ungrounded "theory" such as spirituality, in Heidegger's terms Dasein, and in Nouwen's language "a new way of being in the world without being of it". Sein pertains to objectified and empirical data and Dasein to what Gerben Heitink (2000:73) calls "transendentiebesef" (a sense of transcendence - in other words, the spiritual dimension of being). In positivistic theories of scientific research observable data has been analysed and synthesised by means of inductive and deductive models and methods (see Van der Ven 2000:56-57; cf Mouton 1987:1-29; Swingewood [1984] 2000:10-12). Psychology tends to be enslaved to such a "methodolotary" of deductive or inductive reasoning (see Curt 1984:235-236).

On the other hand, Nouwen's "method" of doing spirituality is that he explores his own spiritual depths in an intuitive way in order to come to an insightful understanding about himself (see Gillespie 2002:117). He applies his understanding to others also, since he believed that "[w]hat is most personal is also the most universal" (Nouwen 1995:7). His "methodological" approach to spirituality is experiential, personal and subjective. "He profoundly and sometimes painfully explores the central theme of God's all-embracing love" (Gillespie 2002:121). His self-exploration provides an experience with which readers can identify and find their own answers. Gillespie (2002:119) puts it as follows: "It seems that Henri Nouwen wanted us to join his experience of the 
adventure of life: learning from it, loving through it and laughing about it together. His self-expression of such adventures drew people to him and led him to believe in individual persons being connected in one universal body."

An example of this epistemology can be seen in his experience of depression during his stay in the Last Daybreak Community, Toronto, Canada, a community for people with mental disability. He worked through this depression by means of 63 "spiritual imperatives" expressed in his diary. These spiritual principles were published shortly after his death as The inner voice of love: $A$ journey through anguish to freedom (Nouwen 1996, in Gillespie 2002:118). Going about his life experiences in this way, Nouwen encountered God and came to self-understanding. “Like St Paul, Nouwen's weakness became a means for his strength. As a 'wounded healer', Nouwen was able to arrive at not merely psychological but spiritual principles through which to live, to heal and to love. In effect, the woundedness of his nature became the means through which he became perfected by grace" (Gillespie 2002:118).

Nouwen's main interest was the spiritual growth of people. As a trained psychologist, he was able to recognize pathology and the way in which that can impede spiritual growth. Psychology, therefore, contributed to his insight into and understanding of personal growth, which includes his special focus on spiritual growth. Psychology, however, should not "have the last nor the only word on interpreting religious experiences" (Gillespie 2002:119). Gillepsie (2002:121) describes Nouwen's spirituality as a "post-Vatican II psycho-spirituality. By taking seriously the psychological perspective, [he has] broadened and deepened our understanding of the divine-human encounter."

In his book, The Living Reminder, Nouwen (1977) explores the connection between spirituality and pastoral care in the context of remembrance, since he sees the pastoral caregiver as the living reminder of Jesus (see Beumer 1997:183-190). He combines this with the categories of healing, sustaining and guiding, used by his teacher Seward Hiltner ([1954] 1958) in his Preface to Pastoral Theology. Nouwen discusses the pastoral caregiver as a "healing reminder", a "sustaining reminder" and a "guiding reminder" of Jesus. 


\section{Beyond psychology: Spirituality in Henri Nouwen's pastoral care}

The article demonstrates how Nouwen understands pastoral care, what the underlying epistemology is and how spirituality is the focal point of his model. He discusses aspects such as pain, anger, greed, grief and solitude. In this discussion his knowledge and use of psychological perspectives become apparent. He sees the suffering person and the pastoral caregiver as people who live in the presence of God. Psychology helps to gain insight into someone's pain, anger, greed, grief and solitude - our "being in the world" (Sein). Spirituality is about the way in which people experience God's presence - a "new way of being in the world without being of it" (Dasein). In order to explain and enhance spirituality, Nouwen finds it imperative that the pastoral caregiver should move beyond psychology. A suffering person needs healing, sustaining and guiding. To elucidate the underlying epistemology of Nouwen's model of pastoral care and to understand his critical stance with regard to psychology the article follows the pattern of the focal points "healing", "sustaining" and "guiding".

\section{LIVING REMEMBRANCE - HEALING}

According to Nouwen, "(h)ealing means revealing that our human wounds are most intimately connected with the suffering of God ... self" (Nouwen 1977:2425). Healing means becoming whole (Hiltner 1958:89). For the pastoral caregiver to be a living reminder of the healing of Jesus, connection would have to be made between the story of individual human suffering and the suffering of Jesus. Healing does not necessarily mean taking away the pain, but rather connecting the individual's pain with the greater human experience of pain. Nothing in the human life is beyond the reach of God's grace. Although psychology helps to understand why pain obstructs self-esteem and authenticity, the challenge, according to Nouwen (1977:26), is to see suffering and pain as part of, not separate from, God's work in this world. When the broken connection is restored healing can become a reality. In this sense the healer does not need psychological techniques or tools to accomplish healing. The suffering person also does not actualise authenticity by means of psychological competency, but does so by a way of being (Dasein). This way of being is characterized by a 
profound spirituality, a way of living in the Spirit. Then the caregiver as healer is a living reminder of Jesus (Nouwen 1977:27-28).

Loss and pain are part of life. For Nouwen (2001:12 - postuum) what happens is not as important as how one responds to it: resentfully or gratefully. Knowledge of what happens is provided by the social sciences, such as psychology. However, from the perspective of spirituality, the challenge is to discover God's Spirit at work and to choose life even in times of trial. "The life of Jesus has made it very clear to us that the spiritual life does not allow bypasses.

When Jesus asks us to take up our cross and follow him (Mark 8:34) we are invited to reach out far beyond our broken and sinful condition and give shape to a life that intimates the great things that are prepared for us" (Nouwen 1975:11-12).

The title of the 2001 book compiled from his writings, Turning my mourning into dancing, reflects how he sees the process of healing. Nouwen (2001:13) quotes Psalm 31, "You have turned my mourning into dancing", to express the centrality of God when people grieve. The Dancer, Jesus, extends his hand to sufferers, helps them up and invites them to move, step by step, out of their suffering until their movement becomes a joyful dance. Without the presence of God, the help of Jesus, pain and grief cause people to become anxious and desperate. Insight into the human experience of pain and grief is provided by psychology. From the perspective of spirituality wounds become a reminder of the need for healing. That need will be met by grace.

Healing is a function of pastoral care (see Heitink 2000:131-135). The pastoral relationship facilitates people to become whole or integrated, encompassing their mental health and well-being in the broadest sense. Wholeness includes the dimensions of body, soul and spirit in interrelationship with one another. In a sense the possibility of healing exists in all human relationships where warmth and closeness are present. The quality of the relationship determines whether the encounter could be experienced as healing. In a pastoral relationship the aim is to create conditions which are conducive to 


\section{Beyond psychology: Spirituality in Henri Nouwen's pastoral care}

healing and integration. Integrated people function as a whole in order to deal effectively with all life situations.

The healing function in pastoral care has biblical roots. The gospels serve as a reminder of the healing activity of Jesus. In New Testament studies Jesus' healings are treated as illustrations of his teaching about the kingdom of God (cf Wilkinson 1998:65). Healings are not an isolated phenomenon. Jesus' teaching and preaching and his healings were concerned with "the good news of the kingdom" (cf Wilkinson 1998:94). The concepts and words pertaining to healing in the New Testament derive from an Old Testament heritage (see Wilkinson 1998:77) and the Graeco-Roman world (Klauck [1995/1996] 2000:289-302). The word most frequently used for healing in the gospels is therapeuo, which also has the connotations of "service" and "worship" (e g Acts 17:25) (Wilkinson 1998:78). A therapon was someone who voluntarily served or attended to another in order to promote their well-being. In the gospels the verb iaomai indicates physical healing (Wilkinson 1998:79). This verb is used as a synonym for sozo and diasozo. This assistance also provides safety from physical dangers or danger caused by divine or human intervention. From a medical-anthropological perspective health in the world of the Bible is understood as a condition of wellbeing (Pilch 1992:26-33; Davies 1995). In four cases the gospels give the motivation for Jesus healing the sick as his feeling of compassion or pity (Mk 8:2//Mt 15:32; Mt 18:27; Lk 10:33; Lk 15:20 - Wilkinson 1998:97-99).

\section{AVAILABILITY - SUSTAINING}

When Nouwen (1977:48-54; see Hiltner 1958:116) describes the caregiver as a reminder of sustaining, availability becomes an issue (cf Wicks 1986). Nouwen $(1977: 49,50)$ points out that "a certain unavailability is essential for the spiritual life of the [caregiver] ... When our absence from people means a special presence to God, then that absence becomes a sustaining absence". Loneliness, for instance, will not be taken away by the presence of another, but rather is understood and felt by the other. This enables the person not to run away from loneliness but accept it as part of his or her basic human condition (Nouwen 1979:92-93). 
The task of the caregiver is to "prevent people from suffering for the wrong reasons" (Nouwen 1979:93). The wrong reason is not understanding and accepting that suffering and wounds are part of being human. Accepting the basic human condition is the beginning of the process of liberation and hope. The shared human condition opens up the possibility for people to find hope and creative ways of mobilising their paralysed lives together, in community and with one another in the presence of God (see Nouwen 1979:93-94). In his book, Reaching out, Nouwen (1975) explains the concept "sharing" in light of "hospitality": ".... The movement from hostility to hospitality makes us reach out to others. The term hospitality was used only to come to a better insight into the nature of a mature Christian relationship to our fellow human being ... To help, to serve, to care, to guide, to heal, these words were all used to express a reaching out toward our neighbor whereby we perceive life as a gift not to possess, but to share" (Nouwen 1975:78). According to Nouwen compassion cannot be separated from community. Compassion reveals itself in community (Nouwen et al 1983:51, 59-61). Here one moves beyond essentialist psychology to the social constructionist notion of persons-in-culture and culture-in-persons.

Social constructionism is an approach to psychological and social science which is embedded in the sociology of knowledge (see Berger \& Luckmann 1967; Coulter 1979; Harré 1986, 1992). This perspective assumes that realities are humanly and socially constructed. According to Curt (1994:233), constructionist approaches are contrasted with essentialist approaches which, for example, view concepts such as "mind", "emotion", "pain", "anger", "grief", and "solitude" as timeless essential things. To say that something is "socially constructed" is to acknowledge that we experience and know rather through social usage in context. Epistemologically seen, Nouwen's approach to healing, sustaining and guiding utilises psychological insights from a social constructionist perspective.

In pastoral care the function of sustaining is to comfort and encourage people in difficult circumstances (see Heitink 2000:135-138). The presence and closeness of another can be experienced as comforting in situations when suffering causes faith to become fragile. Often there is no hope of an improvement in the situation. Through the compassionate presence of another person the comforting presence of God can be experienced. On the other hand 
all difficult situations should not be accepted too readily. Pastoral care as comforting can also include a component of challenging (see Glock et al 1967). Choices made by people with power which are harmful to others can and must be challenged.

\section{RESPONSIBILITY - GUIDING}

According to Nouwen (1977:73) a "guiding reminder" builds on memories, unmasks "the illusion of present comfort" and reminds people of the story of God in order to have hope for the future. The guiding function of pastoral care is supporting people to make their choices in life on account of their own convictions and so develop their independence (see Heitink 2000:139-142). There is often an ethical or religious aspect to the life's choices people have to make. For this they need advice and guidance which fully respect their own responsibilities. Psychology helps to provide the professional caregiver with the professional skills to guide. "Guidance" has the possibility of becoming patronising or exercising power over others. Both the psychologist and the pastoral caregiver as professionals should therefore be careful not to be directive in a coercive way. In a postmodern context, there is room for the expression of own convictions (cf Heitink 2000:142). There is also more space for others to come to their own unique understanding of life and God. The guiding function of pastoral care should be more than simply an analysis of the situation and mirroring it to the other. In this setting the credibility of the caregiver will be determined not only by his or her psychological competency, but by authenticity and the willingness to listen to and accept the stories of others (see Heitink 1999:32). This adds a spiritual dimension to the use of psychological techniques which contributes to the depth of the pastoral relationship (cf Josuttis 1996).

\section{COMPASSION - THE ESSENCE OF AUTHENTICITY}

Nouwen (1981:9-10) fears that Christian leadership has become secularized. He identifies the enemies of spiritual life. Two of them are anger and greed. Caregivers suffer from the human condition of anger which leads to "a biting resentment and slowly paralyzes a generous heart" (Nouwen 1981:11; see Nouwen 1979:71). Psychology gives insight into the essence of anger and greed 
as observable phenomena. Resentment can lead to distance between the caregiver and the person in need of care and prevent the caregiver from being close to people and, from a spiritual perspective, from God. Christian leaders are often rather ill-equipped to offer people "creative ways to communicate with the source of human life" (Nouwen 1979:37-38).

Terminology used in the Bible assists in the understanding of psychological aspects such as anger and resentment from a spiritual perspective. In New Testament Greek the semantic subdomain of "self-control" is part of the larger domain of moral and ethical qualities. This subdomain focuses on the virtues of self-control, restraint and self-discipline so as not to harm others or oneself and not to be tempted by evil (1 Cor 7:5) (see Louw \& Nida 1988:751753). In the same larger domain concerning compassion the negative side is highlighted, instances where compassion is excluded (see Louw \& Nida 1988:754-759). This includes subdomains such as "bad, evil, harmful, damaging", "treat badly" and "act harshly". A subdomain which pertains specifically to negative interaction with others is, for instance, "exploit". This includes words such as those for taking advantage of someone, deceiving by means of trickery and cunning, and deceiving someone by implying that what is offered is valuable while in actual fact it is not.

According to Nouwen (1979:37) it is necessary for pastoral caregivers to learn to understand and articulate their inner world (Nouwen 1979:37). Solitude is the means by which a caregiver can regain a true pastoral identity with God as source (Nouwen 1981:13-14; [1981] 1989:218). One needs more than psychological insight to realise that solitude is not only quiet and peaceful, but includes a "struggle with demons" and an encounter with God (Nouwen 1981:20; cf Nouwen 1979:38-40; 91). Only when caregivers listen to God, can others encounter God through them and only then a compassionate pastoral care becomes possible. Solitude brings one to "die to our neighbors" which to Nouwen means "to stop judging them, to stop evaluating them, and thus to become free to be compassionate. Compassion can never coexist with judgment because 


\section{Beyond psychology: Spirituality in Henri Nouwen's pastoral care}

judgment creates the distance, the distinction, which prevents us from really being with the other" (Nouwen 1981:21).

New Testament vocabulary adds to the understanding of why "compassion can never coexist with judgment". Judgments is found in the sub domains of "envy, jealousy", "resentful, hold a grudge against", "anger", "hate, hateful" (see Louw \& Nida 1988:760-766). The sub domain "despise, scorn, contempt" include concepts representing the opposite of compassion. The sub domain "arrogance, haughtiness, pride" includes words which describe the opposite attitude to that of the humble, compassionate person who prizes simplicity.

Compassion is a desirable trait and generally seen as the human response to suffering. Being compassionate is often equated with being human. On the other hand the human world shows a remarkable lack of compassion. There is much war and hunger, torture and abuse among human beings. This prompts Nouwen (1983 - with co-authors McNeill \& Morrison) to look critically at the understanding of compassion. Rather than using only psychological techniques, he places the emphasis on the meaning of "to suffer with", to share in the hardship of others, to feel this hardship oneself: "Compassion asks us to go where it hurts, to enter into places of pain, to share in brokenness, fear, confusion, and anguish" (Nouwen 1983:41).

Nouwen (1983:4) also acknowledges that it is difficult enough to bear one's own suffering. No one has the desire to cause suffering for themselves by taking upon them the suffering of others. Compassion in this sense is, therefore, not the obvious human response to suffering. It requires "the full immersion in the condition of being human" (Nouwen 1983:4). In the words of Bernard Lonergan (1957:191), quoted by Nouwen (1971:15) this comprises "the outer drama of human living". "Withdrawal" from this means to withdraw to "the inner drama of phantasy". The natural tendency is to rather avoid pain, suffering and being confronted head-on with the human condition (Nouwen 2001:67).

Nouwen (1983:7) quotes Luke 6:36, "Be compassionate as your Father is compassionate", to emphasize that, though compassion might not be the "normal 
human response" to suffering, it is necessary for humanity to "grow into its fullness" (Nouwen 1983:7). The emphasis Luke places on compassion is evident in comparison with the parallel in Matthew 5:48. Matthew interprets the Jesus tradition in the light of the Scriptures when he chooses to use the word "perfect" (teleios) to interpret the word "holiness" (kadosh) in Leviticus 19:2. Luke interprets the Jesus tradition to emphasize Jesus' compassion by rather choosing the word "compassion" (oiktirmon). Nouwen (1983:15-16) sees Jesus as the embodiment of God's compassion in this world. God's compassion is the source of Jesus' compassionate response to those who came to him with their suffering.

The call to be compassionate represents the essence of Christian life. It is, however, not easy to respond to this call because it goes against human nature. The call to compassion requires a response not on account of "what I am" (Sein), but on account of "what I ought to be" (Dasein). According to Heidegger, Sein and Dasein are dialectically related to each other. In Nouwen's frame of reference, Sein can be analysed and understood by means of psychological competency. Dasein pertains to the caregiver's and the suffering person's spiritual well-being. Psychology and spirituality complement each other in a dialectical way similar to the way in which Sein is related to Dasein. Nouwen (1971:63) formulates this insight as follows: "(E)very pastoral contact is a challenge to understand in a new way God's work with people and to distinguish with a growing sensitivity the light and the darkness in the human heart."

To be compassionate requires a "total conversion of heart and mind" (Nouwen 1983:8). One area where change is necessary, is the needs and own interests of the one who listens compassionately to others. Nouwen (1979:90) calls this the "intentions" of the listener getting in the way. They prevent the listener from being present to the other. In order to get one's own intentions out of the way one must be at home with oneself, to "discover the center of his [or her] life in his [or her] own heart" (Nouwen 1979:91).

According to Nouwen (1981:20; cf Nouwen 2001:67-70) compassionate care requires an "inner disposition to go with others to the place where they are weak, vulnerable, lonely, and broken". Those who do want to respond to the 


\section{Beyond psychology: Spirituality in Henri Nouwen's pastoral care}

need of others, do not necessarily want to be vulnerable with the other. The prospect of this is too frightening. They much prefer action, doing something, "fixing the problem". However, it is not the use of psychology as such which provides the remedy. For Nouwen solitude is the way out of this trap. Solitude can mold people into gentle, caring, accepting and forgiving persons. The consequence of this is that the distinctions between people and the difference between doing and being disappears (Nouwen 1981:22). Caregivers who experience Gods presence in their solitude can then really be with others. For postmodern philosophers such as Derrida (1996), Foucault (1972:224) and Levinas (1969:47) respect for the Other ("het anders-zijn van de ander - l'altérité de l'autre"; Van Peursen 1995:47) is to maintain distance in order to create closeness. Compassionate pastoral care means to move closer to people through solitude (Nouwen 1981:24; cf Nouwen 1979:71-72). "According to Levinas (see Phillips 2000:159) God's 'presence' is an 'absence', a trace left in the face of my sister or brother. The face marks God's passing; the face of the other is where God's glory is manifest. The other (autrui) is wholly other (autre)".

In order to become truly present to others in their suffering Nouwen finds "prayer of the heart" indispensable to a ministry of compassion: "Through prayer we can carry in our heart all human pain and sorrow, all conflicts and agonies, all torture and war, all hunger, loneliness, and misery, not because of some great psychological or emotional capacity, but because God's heart has become one with ours" (Nouwen 1981:69). He sees prayer not as a way to escape from reality, but rather as a way to see reality more clearly. With such a clear vision on God the compassionate caregiver can really become involved in reality, can move "into the midst of a tumultuous world" (Nouwen 1981:72; cf Nouwen 1971:xviii; 1979:46-47). Jesus not only became a servant, but was also rejected, knew pain and degradation. Herein Nouwen 1983:26-28) sees the price God through Jesus is willing to pay for intimacy and solidarity with people. The call to compassion means for human beings to follow in Jesus' footsteps. According to Matthew (11:29) Jesus' gentleness is the reason why his followers should learn from him. 
Nouwen (1979:40-41) describes the nature of leadership ("authority") as compassion. Pastoral caregivers are spiritual leaders who sustain and guide others through being healed themselves and through the compassionate healing of others. This happens not through the application of psychological techniques as such. The task of the leader rather is "to make the compassion of God ... credible in his [or her] own world". The compassionate leader is fully engaged with reality, he or she does not conform under pressure, avoids "the distance of pity as well as the exclusiveness of sympathy" (Nouwen 1979: 41). With the help of psychology compassionate leaders can be in touch with their own dark side. As spiritual leaders they themselves are able to forgive and also point others to forgiveness which can be liberating and healing (Nouwen 1979:42). According to Nouwen (1979:72) leadership requires understanding and what is understood should be shared: "The great illusion of leadership is to think that [people] can be led out of the desert by someone who has never been there." Nouwen (1979:7476) emphasises that people will follow a leader if they experience the leader as a wounded healer who truly cares for them in a spiritual way, in other words who enhances their Dasein.

\section{CONCLUSION}

This article is about the use of psychological techniques in the theological discourse. The term "discourse" does not pertain only to a linguistic concept, but to the constructive, productive and pragmatic aspects of language use, rather than the descriptive or representational aspects (Curt 1994:234). This shift in focus was caused by Husserl's and Heidegger's phenomenological emphasis that language can never describe the world in an neutral way. A "theological discourse", for instance, is not a description of "essentialist dogmatic ontology" which, from a positivistic perspective, lies behind the cognition or motivation (as a psychological entity) of religious beliefs. Rather, interaction and intertextuality/ internarrativity are seen as "social practices which are productive of experience and which construct realities in which we live" (Curt 1994:235). In this sense a "theological discourse" consists of all kinds of statements (whether professional 


\section{Beyond psychology: Spirituality in Henri Nouwen's pastoral care}

or lay) which re-construct the reality of spirituality and the experience of being a Christian. In the words of Schleiermacher ([1799] 1879:283), Christian feeling "accompanies every joy and every pain, every love and every fear; yea, it is the chord of pride as of humility, and everything is related to it" (cf Brandt 1941:183).

The underlying epistemology of Nouwen's model of pastoral care is not essentialist positivistic, but rather intuitive. This concurs with Charles Peirce's (1934:414; 1957; see Fann 1970) abductive reasoning. Elliott (1993:48), using Linda Woodson's (1979:1) notion of "intuition", explains this way of knowing as follows: "[It] involves a process of logic that is neither exclusively deductive (from model to material) nor inductive (from material to hypothesis) but inclusive of both in a procedure characterized as 'abduction'. Abduction (also called 'retroduction') is a process in logic of the discovery procedure of working from evidence to hypothesis involving a back-and-forth movement of suggestion checking [intuition - Linda Woodson]." In his epistemology, Schleiermacher used the term "to divine" ("divinatorisch" - i e, "suggesting") to express the dynamics of "suggestion checking" (cf Humm [1989] 1995:131-132).

Abduction does not take for granted that knowledge can be derived by means of applying rigorous, linearly derived methods such as deduction or induction where one descriptively proceeds from the sample to the whole (see Stephenson 1961:11). Abduction is a "practical craft" (Curt 1994:232) by means of which one explores the possibility of knowledge in a "re-constructive" way via understandings, interpretations and explanations which are conducted by taking the nature of discourse, that is "persons-in-culture"/"culture-in-persons" seriously. And the preliminary end "product" could be "inconclusion" in stead of "conclusion".

This article illustrated Nouwen's insight (pointed out by Gillespie) that psychology can contribute to our knowledge of our being as Sein, but does not sufficiently explain our Dasein, that is our living presence in relation to God and Others. According to Nouwen's way of knowing it is important to identify where psychological and theological discourses are incommensurable because of their conflicting epistemologies. It is also important to distinguish the facets of these 
discourses which can be complementary. A multidisciplinary approach, which includes psychology, can be utilised to explain persons-in-culture and culture-inpersons in a comprehensive way and to understand their pain, anger, grief, greed and solitude.

In order to heal, sustain and guide people in a spiritual way the caregiver is engaged in a theological discourse. This discourse is complemented by psychology when the focus is on Sein. When the focus shifts to Dasein the theological discourse moves beyond psychology. The reason for this is the distinctive epistemologies of the psychological and the theological discourses. This is an insight of Henri Nouwen which, tested in this study by an investigation of his model of pastoral care, was found to be relevant for practical theology in an increasingly postmodern context .

\section{Works consulted}

Beumer, J [1996] 1997. Onrustig zoeken naar God: De spiritualiteit van Henri Nouwen. Tielt: Lannoo.

Berger, P \& Luckmann, T [1967] 1975. The social construction of reality: A treatise in the sociology of knowledge. Harmondsworth: Penguin.

Brandt, R B 1941. The philosophy of Schleiermacher: The development of his theory of scientific and religious knowledge. Westport, CT: Greenwood Press.

Brennan, T 1978. An interview with Henri Nouwen. The Critic 36(4), 1982.

Browning, D S [1991] 1996. A fundamental practical theology: Descriptive and strategic proposals. Minneapolis, MN: Fortress.

Collins, J \& Selina, H [1999] 2001. Introducing Heidegger. Cambridge: Icon Books.

Coulter, J 1979. The social construction of mind. Bassingstake: Macmillan.

Curt, B C 1994. Textuality and tectonics: Troubling social and psychological science. Buckingham, PA: Open University Press.

Davies, S 1995. Jesus the healer. London: SCM Press.

Derrida, J 1996. Monolingualism and the Other, or the prosthesis of origin, tr by $\mathrm{P}$ Mensah. Stanford, CA: Stanford University Press.

Elliott, J H 1993. What is social scientific criticism? Minneapolis: Fortress.

Fann, K 1970. Peirce's theory of abduction. The Hague: Martinus Nijhof.

Foucault, M 1972. Archaeology of knowledge. London: Tavistock.

Gillespie, C K 2002. Similarities and differences: The psychologies and spiritualities of Henri Nouwen and Adrian van Kaam. Theoforum 33(1), 105-121. 


\section{Beyond psychology: Spirituality in Henri Nouwen's pastoral care}

Glock, C, Ringer, B \& Babbie, E R 1967. To comfort and to challenge: Adilemma of the contemporary church. Berkeley, CA: University of California Press.

Harré, R 1986. The social construction of emotion. Oxford: Blackwell.

Harré, R 1992. What is real in psychology: A plea for persons. Theory and Psychology 2(2), 153-159.

Heitink, G 1993. Praktische theologie: Geschiedenis, theorie, handelingsvelden. Kok: Kampen.

Heitink, G 1997. Ontwikkelingen in de praktische theologie. Praktische Theologie. Nederlands Tijdschrift voor Pastorale Wetenschappen 5, 558-581.

Heitink, G 1999. Praktische theologie in de context van de moderniteit. Een overzicht. Nederlands Theologische Tijdschrift 53, 25-41.

Heitink, G [1998] 2000. Pastorale zorg: Theologie, differentiatie, praktijk. 2e druk. Kampen: Kok. (Handboek Praktische Theologie.)

Hiltner, S [1954] 1958. Preface to pastoral theology. New York: Abingdon.

Humm, M [1989] 1995. The dictionary of feminist theory. Second edition. London: Harvester Wheatsheaf.

Josuttis, M 1996. Die Einführung in das Leben: Pastoraltheologie zwischen Phänomenologie und Spiritualität. Gütersloh: Gütersloher Verlag.

Klauck, H-J [1995/1996] 2000. The religious context of early Christianity: A guide to Graeco-Roman religions, tr by B McNeil. Edinburgh: T \& T Clark.

Levinas, E 1969. Totality and infinity: An essay on exteriority, tr by A Lingis. Pittsburg, A: Duquesne University Press.

Lonergan, B 1957. Insight. London: Lonmans Green.

Louw, J P \& Nida, E A (eds) 1988. Greek-English Lexicon, Vol 1: Introduction \& domains. Broadway, NY: United Bible Societies.

Mouton, J 1987. Die positivisme, in Snyman, J J \& Du Plessis, P G W (reds), wetenskapsbeelde in die geesteswetenskappe, 1-29. Pretoria: RGN. (RGNStudies in Navorsingsmetodologie 3.)

Nouwen, H J M 1971. Creative ministry. New York: Doubleday.

Nouwen, H J M 1975. Reaching out: The three movements of the spiritual life. New York: Doubleday.

Nouwen, H J M 1977. The living reminder: Service and prayer in memory of Jesus Christ. New York: Seabury. (A Crossroad Book.)

Nouwen, H J M 1979. The wounded healer. New York: Doubleday.

Nouwen, H J M 1981. The way of the heart. New York: Ballantine Books.

Nouwen, H J M [1981] 1989. The Genesee Diary: Report from a Trappist Monastery. New York: Doubleday.

Nouwen, H 1988. The road to daybreak: A spiritual journey. New York: Doubleday. 
Nouwen, H J M 2001 (postuum). Turn my mourning into dancing: Moving through hard times with hope, complied and edited by T Jones. Nashville, TN: W Publishing Group.

Nouwen, H J M, Mc Neill, D P \& Morrison, D A 1983. Compassion: A reflection on the Christian life. New York: Doubleday.

Phillips, G A 2000. Levinas, in Adam, A K M (ed), Handbook of postmodern Biblical interpretation, 154-159. St Louis, MS: Chalice Press.

Peirce, C S 1934. On seleceting hypotheses, in Hartsgorn, C \& Weiss, P (eds), Collected papers of Charles Sanders Peirce, Vol 5: Pragmatism and pramaticism. Cambridge, MA: Harvard University Press.

Peirce, C 1957. The logic of abduction, in Essays in the philosophy of science. New York: The Liberal Arts Press.

Pilch, J J 1992. Understanding healing in the social world of early Christianity. Biblical Theology Bulletin 22(1), 26-33.

Ruffing, J 1990. Psychology as a resource for Christian spirituality. Horizons 17, 47-59.

Schleiermacher, F D E [1799] 1879. Über die Religion: Reden an die gebildeten unter ihren Verächtern. Critical Edition by G C B Pünjer. Jena.

Stephenson, W 1961. Scientific creed. Psychological Record 11, 1-26.

Swingewood, A [1984] 2000. A short history of sociological thought. Third edition. Hampshire: Palgrave.

Van der Ven, J A 2000. Pastoraal perspectief: Vorming tot reflektief pastoraat. Kampen: Kok. (Theologie \& Empirie.)

Van Peursen, C A 1995. Na het postmodernisme: Van metafysica tot filosofisch surrealisme. Kampen: Kok Agora.

Wicks, R 1986. Availability: The problem \& the gift. New York: Paulist Press.

Wilkinson, J 1988. The Bible and healing: A medical and theological commentary. Edinburgh: Handsel Press.

Woodson, L 1979. A handbook of modern rhetorical terms. Urbana, II: National Council of Teachers of English. 